\title{
Uma sopa de ideias
}

A soup of ideas

Una sopa de ideas

SOPA DE WUHAN: PENSAMIENTO CONTEMPORÁNEO EN TIEMPOS DE PANDEMIAS. Agamben G, Zizek S, Nancy JL, Berardi F, Petit SL, Butler J, Badiou A, Harvey D, Han B-C, Zibechi R, Galindo M, Gabriel M, González GY, Manrique P, Preciado PB. ASPO (Aislamiento Social Preventivo y Obligatorio); 2020. 188 p. https://bit.ly/sopadewuhan.

doi: 10.1590/0102-311X00108220

O livro digital Sopa de Wuhan: Pensamiento Contemporáneo en Tiempos de Pandemias ${ }^{1}$ pode ser baixado gratuitamente no site do coletivo de midiativismo https://www.medionegro.org. Essa obra reúne intervenções de uma série de pensadores de várias partes do mundo sobre o tema da atual pandemia de COVID-19. Como indicado no texto de apresentação, essa publicação é a primeira do projeto editorial Aislamiento Social Preventivo y Obligatorio (ASPO) e não consiste na veiculação de material original, mas tão somente na seleção curatorial e edição no formato de livro de textos já publicados em outros meios.

O livro apresenta contribuições de 15 autores: Giorgio Agamben, Slavoj Zizek, Jean Luc Nancy, Franco “Bifo” Berardi, Santiago López Petit, Judith Butler, Alain Badiou, David Harvey, Byung-Chul Han, Raúl Zibechi, María Galindo, Markus Gabriel, Gustavo Yañez González, Patricia Manrique e Paul B. Preciado. A primeira contribuição é de Agamben, em 26 de fevereiro de 2020, e a última é de Paul Preciado, em 28 de março do mesmo ano. Além da seleção dos textos, a intervenção do editor se restringiu a indicar data de publicação, meio em que foi publicado originalmente e informações biográficas sobre o autor de cada texto.

Agamben é o único autor com mais de uma contribuição, contando três participações. Embora seja nítido o predomínio de vozes ocidentais e do norte global (Espanha, Estados Unidos, França e Itália), é garantido algum espaço no rol de autores selecionados para intervenções do Oriente e de países periféricos (Bolívia, Chile, Coreia do Sul, Eslovênia e Uruguai). Há também desequilíbrio em termos de representatividade de gênero: dos 15 autores, 11 são homens cis. Por outro lado, há muita diversidade de estilos de exposição e mesmo gêneros textuais: artigos de opinião, postagens em blogues, diários, crônicas, manifestos... Os argumentos e conclusões desenvolvidos pelos autores são também os mais variados, sendo difícil encontrar um denominador comum às várias contribuições além do compromisso com uma atitude crítica, o que talvez seja o ponto mais forte do livro.

É grande a dispersão de avaliações sobre o sentido de novidade da pandemia de coronavírus. Para Agamben, por exemplo, a reação, a seu ver, desproporcional do governo italiano com suas "medidas frenéticas, irracionais e injustificadas" [sic] de restrição às liberdades individuais deve ser interpretada como parte da tendência cres- 
cente de "usar do estado de exceção como paradigma normal de governo".

Badiou, por sua vez, partindo de uma perspectiva de análise marxista da relação entre Estado e sociedade civil, aponta a "aterradora simplicidade e ausência de novidade da situação epidêmica atual". Para Badiou, as medidas de exceção tomadas por governos como o da França provavelmente não terão "consequências políticas significativas” no pós-pandemia. Essas medidas apenas reproduzem um padrão já conhecido em que, confrontado por um inimigo externo (guerra, desastres naturais), o Estado toma medidas de exceção para fazer prevalecer interesses mais gerais do que aqueles imediatos da burguesia, enquanto preserva estrategicamente os alicerces da dominação burguesa no longo prazo.

No extremo oposto vai a avaliação de Zizek, que descarta como ilusórias as expectativas de breve retorno à normalidade e aposta alto que, por seus efeitos profundamente disruptivos, a pandemia pode vir a ser a gota d'água que sinalizaria o fim do comunismo chinês. Seria algo semelhante ao que o desastre de Chernobyl foi para o comunismo soviético ou ainda um golpe fatal ao estilo Kill Bill no capitalismo internacional, "um sinal de que não podemos seguir pelo mesmo caminho que viemos até agora, de que precisamos de uma mudança radical".

Han se contrapõe diretamente à hipótese levantada por Zizek ao constatar a maior eficácia das políticas de controle da pandemia nos países orientais (China, Coreia do Sul, Taiwan), devido ao uso mais intensivo de big data e tecnologias de monitoramento nesses países. De acordo com Han, o prognóstico mais provável não é, portanto, que o modelo chinês esteja com os seus dias contados, mas, ao contrário, que se torne cada vez mais uma referência a ser "importada" por outros países. Nesse sentido, a orientação estratégica dos países orientais no combate à pandemia vai além da noção defasada de soberania (como capacidade de decretar estado de exceção e o abrir ou fechar de fronteiras) à qual os governos ocidentais têm se apegado de forma quase ritualística, e sinaliza para uma redefinição do poder soberano, entendido agora como capacidade de controlar grandes volumes de dados.

Manriqe segue uma linha parecida ao apontar a inconveniência de categorias políticas tradi- cionais da teoria contratualista liberal para lidar com a pandemia global de coronavírus. Ao não diferenciar fronteiras nacionais e de classe social, o vírus quebrou a redoma de invulnerabilidade que envolvia a classe média europeia. Com isso, tem levado a uma desestabilização de noções de comunidade e imunidade herdadas de uma tradição de modernidade-colonialidade calcada, desde suas origens até o presente, na produção sistemática de sub-humanos. Assim, para Manrique, o desafio mais imediato posto à inteligência crítica seria o de pensar uma imunidade virtuosa, fundada em uma noção de múnus (obrigação com os enfermos e vulneráveis) capaz de abranger uma comunidade cidadã ampliada em termos cosmopolitas, livre da retórica belicista e de pureza racial, politicamente consciente de seu processo de autocriação e mais aberta à mestiçagem e cruzamento de fronteiras.

Galindo reverbera várias dessas preocupações ao colocar diretamente a questão sobre "o que acontece quando o coronavírus chega a países como a Bolivia?”. Marcando o lugar de diferença periférica de uma "sociedade proletarizada, sem salários, sem postos de trabalho, sem indústria, onde a grande massa sobrevive na rua em um tecido social gigantesco e desobediente", Galindo aponta o que entende como inadequação das "medidas copiadas" e chama provocativamente à necessidade de “...repensar o contágio. Cultivar o contágio, expornos ao contágio e desobedecer para sobreviver", não como "ato suicida", mas como mero exercício de "bom senso" orientado para uma "autogestão social da enfermidade, da debilidade, da dor, do sofrimento, do pensamento e da esperança”. Esse posicionamento, em termos práticos, inclui se preparar para a provável "gestão majoritariamente domiciliar da enfermidade”, mudar de hábitos alimentares para aumentar a resistência à doença, buscar e explorar com os próprios corpos remédios não farmacêuticos e conhecimentos tradicionais, "...tudo isso que nos ensinaram a desprezar".

O texto de Preciado, que encerra a coletânea, identifica a epidemia como "...laboratório de inovação social, a ocasião de uma reconfiguração em grande escala de técnicas de corpo e tecnologias de poder". Preciado identifica no momento atual o aprofundamento de processos que já estavam em curso e que envolvem a passagem de uma sociedade industrial, escrita e orgânica, em que predominam 
formas de controle disciplinar e arquitetônicas, para uma sociedade imaterial, cyber e digital, em que predominam formas de controle microprotéticas e cibernéticas.

Acompanhando essas mudanças, o lócus de exercício preferencial da produção de corpos politicamente dóceis e economicamente úteis tende a se deslocar para fora das instituições disciplinares de confinamento e normalização (prisões, escolas, fábricas, quartéis, hospitais). Nesse sentido, Preciado nos convoca a "passar de uma mutação forçada a uma mutação deliberada”, encarando o momento necessário de quarentena como campo de batalha em que nossos domicílios e celulares pessoais são colocados em disputa como espaço de teletrabalho e vigilância voluntária ou de emancipação cognitiva e resistência.

Para o leitor brasileiro, é inevitável algum grau de estranhamento em relação a boa parte das discussões travadas em "Sopa de Wuhan", o que se deve, em parte, a certo descompasso existente entre a forma como o governo Jair Bolsonaro tem lidado com a pandemia e aquela seguida pela maioria dos governos do mundo: enquanto lá fora os maiores temores neste momento dizem respeito à possível perda de liberdades individuais, aqui lutamos para que as decisões de políticas públicas levem em conta evidências científicas. Em todo caso, essa é uma leitura que vale a pena não só como forma de se manter atualizado com o que se discute além do nosso quintal, mas também pela qualidade geral de frescor e estímulo ao pensamento dos textos aí reunidos.

Pedro Henrique Santos Queiroz 1

1 Universidade Estadual de Campinas, Campinas, Brasil. queirozsantoshenriquepedro@gmail.com

1. Agamben G, Zizek S, Nancy JL, Berardi F, Petit SL, Butler J, et al. Sopa de Wuhan: pensamiento contemporáneo en tiempos de pandemias. ASPO (Aislamiento Social Preventivo y Obligatorio); 2020. https://bit.ly/sopadewuhan. 